\title{
Mineral Composition of Seaweeds from Coral Islands of the Pacific Ocean as a Function of Environmental Conditions
}

\author{
N. K. Khristoforova and N. N. Bogdanova \\ Pacific Institute of Geography, Far East Science Center, Academy of Sciences of the USSR, Vladivostok 690 670, USSR
}

\begin{abstract}
Contents of $\mathrm{Fe}, \mathrm{Mn}, \mathrm{Cu}, \mathrm{Zn}$ and $\mathrm{Pb}$ were determined in Caulerpaceae seaweeds from shallows of coral islands in the south-western Pacific Ocean. Differences have been found in natural chemical properties of island environments in central and outer regions of the Ocean. Geochemical properties of island waters are shown to influence the mineral composition of the macrophytes studied.
\end{abstract}

\section{INTRODUCTION}

In a previous paper (Khristoforova et al., 1979) we investigated the heavy-metal content in the bivalve Tridacna squamosa from coastal waters of south-western Pacific islands as a function of ambient geochemical conditions. This investigation has ascertained that the mineral composition of the bivalve tissues depends on the chemical compositions of rocks forming the islands, those of coastal waters, and on conditions of water exchange in habitats of $T$. squamosa.

In the present paper we have studied the content of $\mathrm{Fe}, \mathrm{Mn}, \mathrm{Cu}, \mathrm{Zn}$ and $\mathrm{Pb}$ in seaweeds of coral islands. Thus, a most important geochemical factor of the environment - the chemical composition of the substratum on which the seaweeds grow - remained constant throughout the study; the biogenic carbonate rock, forming the islands, was the same in all the cases.

\section{MATERIALS AND METHODS}

Common inhabitants of shallow waters of tropical coral islands, Caulerpaceae (green seaweeds) grow in places remote from intensive surfs, i.e. in calm waters (Vinogradova, 1977). We studied closely related species of seaweeds belonging to the genera Caulerpa and Halimeda (Family Caulerpaceae) collected near the Bio Island (Solomon Islands) and on Suvorov and Pukapuka (Danger) Atolls (Cook Islands). Halimeda, unlike Caulerpa, has calcareous thalli and plays a significant role in building coral reefs.
On Suvorov Atoll, samples were mainly collected near Anchorage Island situated north-east of the ring reef. The margin of the reef flat, fringing the island, faces the passage of the lagoon and drops abruptly 2-2.5 $\mathrm{m}$. The vertical wall features numerous crevices, furrows and caverns and is populated by corals, bivalve molluscs and seaweeds. Over the whole height of the wall grow large- and small-sized Halimeda: $H$. taenicola Taylor and $H$. micronesica Yamada, which contribute about $50 \%$ of all local seaweeds. At a depth of $1.5 \mathrm{~m}$ the prostrate-blistered alga Caulerpa racemosa and the fir-like $C$. urvilliana Mont. appear. From a depth of $0.7 \mathrm{~m}$, among Halimeda and, further, Caulerpa, Phipilia orientalis A. et E occurred. The bottom at the foot of the wall was sandy.

Some samples were taken near the Mote-Tou Island situated at the south-western side of the atoll. Caulerpa urvilliana was collected from the inner reef flat and coral heads at a depth of $0.6-1.5 \mathrm{~m}$. In shallow reef waters, seaweeds are rare but on the walls of the reef flat and coral heads, which occur in the lagoon, their number increases considerably.

In the Pukapuka Atoll, samples of seaweeds were collected down south, near the horseshoe-like MotuKoe Island with its convex side facing the ocean and its concave side facing the lagoon. The sandy shore of the inlet inside the 'horseshoe' of the island gradually slops down. The benthic population is poor: on fine, easily suspended sand one can see only black holothurians. To the center of the lagoon (depth to $15 \mathrm{~m}$ ) coral 'tables', sometimes rather expanded appear. The seaward reef flat was investigated. Here, the bottom was 
covered with coarse sand and coral debris. At about $1.5 \mathrm{~m}$ depth coral heads occurred, on which Caulerpa urvilliana was frequent; some Halimeda micronesica was also present.

At the small Bio Island, the shallow lagoon was investigated from the northern headland towards the reefs, beyond which was a drop-off. An exposed part of the intertidal zone consisted of weathered corallite plates. In water, these are gradually replaced by sand. The slope was very gentle. At a depth down to $1 \mathrm{~m}$, Caulerpa peltata Lamour grew in large and dense patches accounting for $20-25 \%$ of the total amount of local seaweeds. At depths of $0.4-0.8 \mathrm{~m}$, we found abundant small and large Halimeda, namely $H$. simulaus and $H$. discoidea Dcne. Beginning from a depth of $1 \mathrm{~m}$ (about $100 \mathrm{~m}$ off shore), $H$. discoidea grew almost alone in the lagoon. The stony bottom was covered with white fine sand, easily suspendible.

The seaweeds collected were washed in sea water and dried in a vacuum drier at $85^{\circ} \mathrm{C}$. After hard acid mineralization, we determined (atomic-absorption spectrophotometer 'Perkin-Elmer-403') the metal content of the $\mathrm{HCl}$ solution. From all collected seaweeds, a herbarium was made.

In order to assess the geochemical conditions of various habitats, in areas of seaweed sampling and in some adjacent waters, water samples were taken in which - after filtration through membrane filters $(0.45 \mu \mathrm{m}$ pore size) and chemical concentration (extraction of chelates by chloroform as diethylditiocarbaminates) - dissolved metal concentrations were determined. Using orthophenanthroline, we determined in all samples the Fe content colorimetrically: (1) the total content (from unfiltered, vaporized and mineralized samples), (2) the dissolved total (from samples mineralized by $\mathrm{HNO}_{3}$ ), and (3) the dissolved free content (from untreated filtrates).

\section{RESULTS}

Table 1 lists the metal contents determined. In species of Caulerpa and Halimeda from Suvorov and Pukapuka Atolls the amounts recorded were lower in seaweeds from Bio Island. We found no Pb in seaweeds of the atolls: it is likely that $\mathrm{Pb}$ concentrations were very small and beyond the sensitivity of the method used for analysis. However, the $\mathrm{Pb}$ content in seaweeds from coastal waters of the Bio Island was considerable, approximating concentrations determined for $\mathrm{Cu}$ (2.46-3.69 ppm dry matter). The seaweeds studied differed significantly in Fe content. Minimal Fe content

Table 1. Metal content of seaweeds from coral islands. Values expressed as $\mu \mathrm{g} \mathrm{g}^{-1} \mathrm{dry}$ matter

\begin{tabular}{|c|c|c|c|c|c|c|c|}
\hline $\begin{array}{l}\text { Location } \\
\text { of station }\end{array}$ & $\begin{array}{l}\text { Date of } \\
\text { sample }\end{array}$ & $\begin{array}{l}\text { Seaweed } \\
\text { species }\end{array}$ & $\mathrm{Fe}$ & $\mathrm{Mn}$ & $\mathrm{Zn}$ & $\mathrm{Pb}$ & $\mathrm{Cu}$ \\
\hline $\begin{array}{l}\text { Suvorov Atoll } \\
\text { Motu-Tou Is., } \\
\text { reef flat }\end{array}$ & 13. II. & $\begin{array}{l}\text { Caulerpa } \\
\text { urvilliana }\end{array}$ & 19.40 & 9.45 & 3.73 & $\begin{array}{l}\text { not } \\
\text { found }\end{array}$ & 1.24 \\
\hline \multirow[t]{3}{*}{$\begin{array}{l}\text { Suvorov Atoll } \\
\text { Anchorage Is., } \\
\text { wall of reef flat }\end{array}$} & 14. II. & $\begin{array}{l}\text { Caulerpa } \\
\text { racemosa }\end{array}$ & 15.15 & 4.63 & 9.02 & $\begin{array}{l}\text { not } \\
\text { found }\end{array}$ & 1.95 \\
\hline & & $\begin{array}{l}\text { Halimeda } \\
\text { taenicola }\end{array}$ & 27.62 & 6.43 & 5.95 & $\begin{array}{l}\text { not } \\
\text { found }\end{array}$ & 2.86 \\
\hline & & $\begin{array}{l}\text { Halimeda } \\
\text { micronesica }\end{array}$ & 25.99 & 7.43 & 6.93 & $\begin{array}{l}\text { not } \\
\text { found }\end{array}$ & 2.97 \\
\hline \multirow[t]{2}{*}{$\begin{array}{l}\text { Pukapuka Atoll } \\
\text { Motu-Koe Is., } \\
\text { reef flat }\end{array}$} & 17. II. & $\begin{array}{l}\text { Caulerpa } \\
\text { urvilliana }\end{array}$ & 54.50 & 7.25 & 9.00 & $\begin{array}{l}\text { not } \\
\text { found }\end{array}$ & 2.25 \\
\hline & & $\begin{array}{l}\text { Halimeda } \\
\text { micronesica }\end{array}$ & 25.12 & 7.14 & 6.65 & $\begin{array}{l}\text { not } \\
\text { found }\end{array}$ & 3.20 \\
\hline \multirow[t]{3}{*}{$\begin{array}{l}\text { Bio Island } \\
\text { Lagoon between } \\
\text { island and reef }\end{array}$} & 22. XII. & $\begin{array}{l}\text { Caulerpa } \\
\text { peltata }\end{array}$ & 72.66 & 7.64 & 8.87 & 3.69 & 2.22 \\
\hline & & $\begin{array}{l}\text { Halimeda } \\
\text { discoidea }\end{array}$ & 45.37 & 6.94 & 10.88 & 3.01 & 3.01 \\
\hline & & $\begin{array}{l}\text { Halimeda } \\
\text { simulaus }\end{array}$ & 41.63 & 6.90 & 9.85 & 2.46 & 3.20 \\
\hline
\end{tabular}


(19.40 and $15.15 \mathrm{ppm}$ ) occurred in Caulerpa of Suvorov Atoll; the maximal one, in Caulerpa of the Bio Island (72.66 ppm). Halimeda from the same places also differed in Fe content: 27.62 and 25.99 ppm dry matter for Suvorov Atoll and 45.37 and 41.63 ppm dry matter for the Bio Island.

Differences in $Z$ n content were less pronounced. For example, the $\mathrm{Zn}$ concentration in Halimeda from Suvorov Atoll was 5.95 and 6.93 ppm; in those from Bio Island, 10.88 and $9.85 \mathrm{ppm}$. Cu concentrations ranged from 1.24 to $2.22 \mathrm{ppm}$ in Caulerpa, and from 2,86 to $3.20 \mathrm{ppm}$ in Halimeda. No significant differences were found in Mn content of seaweeds from different areas.

Seaweeds from atolls also differed in their metal concentrations. Although such variations were less appreciable than between those of atolls and Bio Island, we succeeded in finding them within one species, Caulerpa urvilliana. The contents of $\mathrm{Fe}, \mathrm{Zn}$ and $\mathrm{Cu}$ in $\mathrm{C}$. urvilliana from Suvorov and Pukapuka Atolls were $19.40,3.73,1.24$ and $54.50,9.00,2.25$ ppm, respectively.

The lowest concentrations of $\mathrm{Cu}$ and Fe occurred in both Caulerpa species from Suvorov Atoll. Caulerpa species revealed considerable variations in Fe concentrations as a function of habitat conditions. Strongly calcareous seaweeds of the genus Halimeda collected in the same regions exhibited smaller variations in $\mathrm{Fe}$ content.

\section{DISCUSSION}

The chemical composition of rocks which form the shores of islands can noticeably influence the geochemical characteristics of near-island waters as well as the mineral composition of local organisms (Khristoforova et al., 1979). All island shores studied here consist of the same type of rock: coral lime-stone, poor in microelements. Located in the open ocean, in clear waters, the islands are neither populated nor subjected to any anthropogenic influences. Nevertheless, the seaweeds collected near these islands significantly differ in their microelement composition.

As is known, the mineral composition of seaweeds is affected by a number of factors: the time of sampling which determines both the physiological state of an organism and the hydrochemical characteristics of ambient waters; the depth of occurrence; the morphology and structure of thalli. However, of dominating influence are geochemical factors: the absolute and relative concentrations of elements in the seaweed habitat. In our opinion, the differences found in metal contents of seaweeds from coral islands, are mainly due to differences in geochemical conditions of the environment.
Suvorov and Pukapuka atolls are oceanic islands, situated in a remote region of the ocean, rather isolated from continents (Voronov et al., 1977). They are reef formations on submerged volcanic cones. In spite of the identity of rocks, forming the atolls, and the same position in the system of oceanic structures, each atoll features its own ecological peculiarities. The lagoon of Suvorov Atoll is deep (to $90 \mathrm{~m}$ ), has a passage to and an active water exchange with the ocean. Element concentrations in water over various sites of seaweeds sampled within this atoll differed only slightly from those of water samples taken outside the outer reef flat (Table 2). It is assumed, therefore, that the microelement composition of seaweeds of the lagoon depends basically on the composition of the oceanic water entering the lagoon.

Pukapuka Atoll is formed by a closed-ring reef flat and has a shallow lagoon (to $15 \mathrm{~m}$ ), well heated and with increasing concentrations of elements towards its center. Probably, this was the reason why the contents of metals in Caulerpa and Halimeda were greater here than in Suvorov Atoll. This difference was particularly pronounced in Caulerpa urvilliana. In Pukapuka Atoll, this seaweed contained $\mathrm{Cu}, \mathrm{Zn}$ and Fe 1.8, 2.4 and 2.7 times more than in Suvorov Atoll.

The Bio Island is similar in its structure to the atolls studied. But it is situated in an outlying area of the ocean, within the shelf zone of the large San-Cristobal Island. Its lagoon is shallow. The reefs form an open ring, and waters of the lagoon easily mix with oceanic waters

As can be seen from Table 2, the coastal waters of the Bio Island contain higher concentrations of dissolved $\mathrm{Zn}$ and $\mathrm{Pb}$ than the atoll waters. But the content of $\mathrm{Cu}$ and $\mathrm{Fe}$ in filtrates of these waters is small. We believe that results on the content of metals dissolved in waters do not adequately reveal the chemical factors of the environment, while sorption on suspended particles and binding of elements by metabolites of marine organisms considerably decrease the concentration of elements in a free form. This, probably, explains our data for the lagoon of the Bio Island - characterized by considerable water motion, great quantities of fine sand and abundant populations - where we found low concentrations of dissolved $\mathrm{Cu}$ and $\mathrm{Fe}$. Beyond the reef bar, in the zone of strong wave action, no free Fe was found, though in mineralized samples (both filtered and, especially, unfiltered) concentration of this metal was the highest, when compared to that from other areas. Thus, information on total, dissolved total and dissolved free iron made it possible to assess the hydrochemical situation of the environment more adequately.

An increased amount of metals in coastal waters of Bio Island seems to be related to its location; this island 
Table 2. Contents of dissolved metals and total $\mathrm{Fe}\left(\mu \mathrm{g} \mathrm{l}^{-1}\right)$ in near-island waters of coral islands

\begin{tabular}{|c|c|c|c|c|c|c|c|c|}
\hline Locality of sampling & $\begin{array}{l}\text { Depth } \\
(\mathrm{m})\end{array}$ & $\mathrm{Cu}$ & $\mathrm{Zn}$ & $\mathrm{Pb}$ & $\mathrm{Mn}$ & $\mathrm{Fe}$ & $\mathrm{Fe}_{\mathrm{dis}}{ }^{\circ}$ & $\mathrm{Fe}_{\text {total }}$ \\
\hline $\begin{array}{l}\text { Suvorov Atoll } \\
\text { Anchorage Is., wall of reef flat }\end{array}$ & 2.0 & 3.4 & 24.8 & 4.1 & 8.8 & 4.0 & 8.0 & 23.0 \\
\hline $\begin{array}{l}\text { Suvorov Atoll } \\
\text { Motu-Tou Is., reef flat in front of } \\
\text { drop-off to lagoon }\end{array}$ & 0.8 & 3.9 & 5.0 & 2.3 & 7.2 & 6.0 & 14.0 & 16.0 \\
\hline $\begin{array}{l}\text { Off Suvorov Atoll } \\
1.5 \mathrm{~km} \text { off shore }\end{array}$ & 1500 & 5.2 & 26.0 & 3.5 & 11.4 & $\begin{array}{l}\text { not } \\
\text { found }\end{array}$ & 3.0 & 8.0 \\
\hline $\begin{array}{l}\text { Pukapuka Atoll } \\
\text { Motu-Koe Is., reef flat }\end{array}$ & 1.5 & 4.0 & 16.2 & 1.5 & 13.8 & 9.0 & 17.0 & 21.0 \\
\hline $\begin{array}{l}\text { Pukapuka Atoll } \\
\text { Center of lagoon }\end{array}$ & 15.0 & 12.0 & 100.0 & 6.8 & 45.0 & 16.0 & 27.0 & 30.0 \\
\hline $\begin{array}{l}\text { Pukapuka Atoll } \\
\text { Outer side of fringing reef }\end{array}$ & - & 5.4 & 26.1 & 3.4 & 23.1 & 4.0 & 13.0 & 15.0 \\
\hline $\begin{array}{l}\text { Bio Island } \\
\text { Lagoon between island and reef, } \\
100 \mathrm{~m} \text { off shore }\end{array}$ & 1.5 & 4.1 & 27.0 & 8.2 & 16.4 & 5.0 & 25.0 & 44.0 \\
\hline $\begin{array}{l}\text { Bio Island } \\
800 \mathrm{~m} \text { off shore, } \\
\text { near drop-off }\end{array}$ & 6.0 & 3.0 & 32.8 & 12.5 & 23.3 & $\begin{array}{l}\text { not } \\
\text { found }\end{array}$ & 14.0 & 32.0 \\
\hline
\end{tabular}

is situated in the area of Pleistocene and recent volcanism. In this connection, we would like to mention here the geological work by Taylor and Hughes (1975) at Rennell Island (Solomon Sea, south of Guadalcanal Island). When studing the genesis of bauxites of Rennell Island, the authors concluded that bauxite deposits formed from volcanic ashes of hornblende andesites erupted by Pleistocene and recent volcanoes.

The diameter of residual grains of the ilmenite from sediments of Rennell Island leads us to believe that a volcanic source was $200 \mathrm{~km}$ distant. The nearest known volcano Mbano is situated south-west of the Guadalcanal Island, $180 \mathrm{~km}$ from Rennell Island.

$\mathrm{Bio}$ Island is much nearer, some $100 \mathrm{~km}$ south-east of this volcano. Hence we suggest that ash-falls were the main source of increased trace-metal contents in the coastal waters of that island. This assumption seems to be supported by results of pedological research undertaken during the same expedition by Drs V.O. Targuliyan and P.V. Yelpatyevsky. They found on upper terraces of the island, under an ancient tropical forest, mellow red carbonate ferrallitic soils, which seem to be a product of decomposition of ash sediments associated with lime-stones of the elevated platform.

As already mentioned, Bio Island is situated in the shelf zone of the large San-Cristobal Island. Hence abrasion of shore basalts may be an additional source of increased trace-metal amounts. Table 3 indicates that erupted basalts and andesites contain much larger amounts of elements than do sedimentary carbonate rocks. Furthermore, on the beaches of Bio Island

Table 3. Distribution of elements in different types of rocks. (After Turekian and Wedepohl, 1961; Vinogradov, 1962). All values expressed as \% of rock weight

\begin{tabular}{|c|c|c|c|c|}
\hline \multirow[t]{2}{*}{ Element } & \multicolumn{3}{|c|}{ Igneous rocks } & \multirow{2}{*}{$\begin{array}{c}\text { Sedimentary rocks } \\
\text { carbonates }\end{array}$} \\
\hline & & alts & andesites & \\
\hline $\mathrm{Fe}$ & & 56 & 5.85 & $3.8 \cdot 10^{-1}$ \\
\hline $\mathrm{Mn}$ & 2 & $10^{-1}$ & $1.2 \cdot 10^{-1}$ & $1.1 \cdot 10^{-1}$ \\
\hline $\mathrm{Cu}$ & 1 & $10^{-2}$ & $3.5 \cdot 10^{-3}$ & $4.0 \cdot 10^{-4}$ \\
\hline $\mathrm{Zn}$ & 1.3 & $10^{-2}$ & $7.2 \cdot 10^{-3}$ & $2.0 \quad 10^{-3}$ \\
\hline $\mathrm{Pb}$ & 8.0 & $10^{-4}$ & $1.5 \cdot 10^{-3}$ & $9.010^{-4}$ \\
\hline
\end{tabular}

pumice-stone fragments washed ashore occur. Finally, as Bio Island does not lie far from large populated islands-microcontinents, one can easily assume anthropogenic pollution effects, especially due to $\mathrm{Pb}$ from motor-car exhaust. In addition, for communication between islands, motor-boats, launches and small planes are used which run on ethyl fuel. Evidently then, suspended particles containing $\mathrm{Pb}$ fall on the water surface, and thus increase the content of this metal in the surface layer. 


\section{CONCLUSIONS}

In marine environments with a strong natural background of elements - e.g. in volcanic areas - or with addition of elements into the surrounding waters due to technogenic impact, a stable local situation can form, which, similar to that of certain land territories (Kovalsky, 1974), may be regarded as a biogeochemical situation characterized by some excess of elements in the environment and local inhabitants. The Bio Island with its shallow waters and resident organisms appears to be such an area.

Although the coral islands are formed by identical rocks, the biogenesis of coral reefs may produce an impact of chemical environmental factors, which, exercising their effect on the biota and reef-building organisms in particular, also affect the mineral composition of coral lime-stones. When decomposing and dissolving, the lime-stone, in turn, adds to the surrounding waters the microelements once abundantly accumulated. Finally, the released elements are incorporated into marine organisms. It therefore is not the environment alone which can influence the chemical composition of organisms, but the organisms themselves can modify the geochemical evolution of the environment.

Acknowledgements. The species studied were kindly identified by Dr. K. L. Vinogradova, an algologist of the Botanic
Institute of the USSR Academy of Sciences (Leningrad); atomic-absorption determinations of elements were performed by Dr. A. I. Obukhov of the Department of Soil Chemistry, Department of Soil Sciences, Moscow University.

\section{IITERATURE CITED}

Khristoforova, N. K., Bogdanova, N. N., Obukhov, A. I. (1979) The content of certain metals in soft tissues of the bivalve mollusc Tridacna squamosa from islands of the tropical zone of the Pacific Ocean in connection with environmental conditions. (Russ., Engl. summary.) Biologiya morya (Mar. Biol., Vladivostok) 3:67-73

Kovalsky, V. V. (1974). Geochemical Ecology. (Russ.) M., Nauka (Science)

Taylor, G. R., Hughes, G. W. (1975). Biogenesis of the Rennell Bauxite. Economic Geology 70: 542-546

Turekian, K. K., Wedepohl, K. H. (1961). Distribution of the elements in some major units of the earth's crust. Bull. geol. Soc. Amer. 72: 175-190

Vinogradov, A. P. (1962). The average contents of chemical elements in main types of erupted mineral rocks of the earth's crust. (Russ.) Geokhimiya (Geochemistry) 7 : 555-571

Vinogradova, K. L. (1977). The class Siphonophyceae. (Russ.) In: The life of plants, 3, Algae, lichens. M., Prosveshcheniye (Education) pp. 297-307

Voronov, A. G., Ignatiev, G. M., Kaplin, P. A. (1977). The trip of the Kallisto to the islands of the Pacific Ocean. (Russ.). Vestnik MGU, ser. Geograph. (Bull. of Moscow University, ser. geography) 5: 111-118 